\title{
PERBEDAAN PENGARUH LATIHAN PLIOMETRIK SQUAT JUMP DAN KNEE TUCK JUMP TERHADAP PENINGKATAN POWER TUNGKAI
}

\author{
Oleh \\ Puji Ratno', Muda Darmawan' \\ ${ }^{1}$ Fakultas Ilmu Keolahragaan, Universitas Negeri Medan \\ Email: mudadarmawan@gmail.com
}

\begin{abstract}
Abstrak
Penelitian ini bertujuan untuk mengetahui apakah ada pengaruh latihan squat jump dan knee tuck jump terhadap peningkatan power tungkai, dan latihan manakah yang lebih baik terhadap peningkatan power tungkai. Penelitian ini dilakukan di Dojo PT Sinar Sosro Tanjung Morawa pada tanggal 25 April - 6 Juni 2017 dengan metode eksperimen. Subyek penelitian berjumlah 20 orang. Hasil penelitian diperoleh power tungkai pada saat pretes pada kelompok latihan squat jump rata-rata sebesar 42,9 dan posttes terdapat peningkatan power tungkai menjadi 52 atau terjadi peningkatan power tungkai sebesar 9,1. Sedangkan pada kelompok latihan knee tuck jump diperoleh rata-rata sebesar 42,3 dan posttes terdapat peningkatan power tungkai menjadi 52,7 atau terjadi peningkatan power tungkai sebesar 10,4. Hasil uji-t antara data pretest dan posttest power tungkai pada kelompok latihan squat jump diperoleh (thitung> $t_{\text {tabel }}$ ) 17,84>1,83 yang berarti ada perbedaan yang signifikan latihan squat jump antara pretest dan posttest. Sedangkan pada kelompok latihan knee tuck jump diperoleh (thitung> $t_{\text {tabel }}$ ) 24,19>1,83 yang berarti ada perbedaan yang signifikan latihan knee tuck jump antara pretest dan posttest. Hasil uji statistik hipotesis ketiga diperoleh thitung sebesar 0,208. Harga tersebut dibandingkan dengan harga $t_{\text {tabel }}$ dengan $\mathbf{d k}=n_{1+} n_{2}-$ $2=10+10-2=18$ pada taraf signifikan $\alpha=0,05$ adalah 2,10. Dengan demikian $t_{\text {hitung }}<t_{\text {tabel }}$ atau $0,208<2,10$. Berarti dapat diambil kesimpulan bahwa secara signifikan latihan Squat Jump tidak lebih besar pengaruhnya dibandingkan dengan latihan Knee tuck Jump terhadap peningkatan power tungkai Karateka Inkanas Dojo PT. Sinar Sosro Tanjung Morawa Tahun 2017.
\end{abstract}

Kata Kunci: Power Tungkai, Latihan, Squat Jump, Knee Tuck Jump.

\section{A. PENDAHULUAN}

Karate adalah olahraga bela diri yang sangat dikenal baik di Indonesia. Perkembangan beladiri yang berasal dari Jepang ini sungguh sangat menakjubkan. Cabang olahraga karate berkembang pesat sejak awal tahun 1970-an hingga kini diseluruh kalangan dan profesi seperti pelajar, karyawan, wiraswasta,masyarakat biasa, instansi pemerintahan, bahkan TNI-POLRI, membentuk perkumpulan karate (dojo) berupaya menciptakan atlet-atlet karate yang tangguh. Di Indonesia sendiri perguruan karate yang berkembang dengan 25 perguruan karate dengan berbagai aliran. Karate 
menjadi menarik untuk dipelajari karena mangandung nilai falsafah dan membentuk karakter individu yang kuat. Menurut Bermahhot Simbolon (2013:1) Karate adalah seni beladiri yang berasal dari Jepang. Terdapat dua kanji dalam Karate yaitu 'Kara' yang berarti kosong dan ' $d o$ ' yang berarti tangan. Karate merupakan seni beladiri yang menggunakan tangan kosong dengan menggunakan serangan berupa pukulan, tendangan, kuncian, bantingan dan lain-lain dengan tujuan untuk melindungi dirinya.

Banyak faktor yang menentukan dalam mendukung keberhasilan untuk berprestasi, seperti faktor teknik, faktor fisik, faktor taktik dan faktor mental. Dari keempat faktor pendukung salah satu yang perlu dilatih dan dikembangkan adalah faktor kondisi fisik, dimana faktor kondisi fisik merupakan faktor yang harus dimiliki dalam upaya pencapaikan prestasi maksimal. Untuk bisa mencapai kondisi fisik yang maksimal, harus disertai dengan latihan. Menurut Josef Nossek, (1982:3) "latihan adalah suatu proses atau dinyatakan dengan kata lain, periode waktu yang berlangsung selama beberapa tahun, sampai atlet tersebut mencapai standar penampilan yang tinggi". Menurut Harsono (1988:153) bahwa sebelum diterjunkan ke dalam gelanggang pertandingan, seorang atlet harus sudah berada dalam suatu kondisi fisik dan tingkatan fitness yang baik.

Salah satu unsur fisik yang harus dilatih dalam cabang olahraga karate adalah power. Sajoto (1988:55) mengemukakan: “daya ledak atau power adalah kemampuan melakukan gerakkan secara eksplosif. Kemudian Bompa (1983:57) menyatakan, "daya ledak merupakan hasil paduan dari kekuatan dan kecepatan kontraksi otot". Power adalah kekuatan otot untuk mengerahkan kekuatan maksimal dalam waktu yang sangat cepat. Dua unsur yang terpenting dalam power adalah : (1) kekuatan otot dan (2) kecepatan otot dalam mengerahkan tenaga maksimal untuk mengatasi tahanan (Harsono, 1988:200). Menurut Bermanhot Simbolon (2013:95) Karate adalah olahraga yang cepat dan meledak-ledak, poin akan didapatkan saat dapat menyerang dengan cukup cepat untuk mengenai sasaran sebelum lawan dapat menghindar.

Untuk bisa melatih power dengan baik, dibutuhkan bentuk latihan yang memungkinkan bisa meningkatkan power. Salah satu bentuk latihan power adalah plyometrics. Plyometrics adalah latihan-latihan atau ulangan yang bertujuan menghubungkan gerakan kecepatan dan kekuatan untuk menghasilkan gerakan-gerakan eksplosif. Radcliffe \& Farentinos (1985:1) menyatakan: "plyometrics is a method of 
developing explosive power. It is also an important component of most athletic performance", atau terjemahannya adalah: 'Pliometrik merupakan metode untuk meningkatkan daya ledak. Selain itu, juga merupakan komponen penting dalam kinerja atletik. Menurut A Chu (1992:81) bahwa "plyometric merupakan latihan khusus yang melatih otot-otot untuk meningkatkan kekuatan maksimum yang lebih cepat.

Radcliffe \& Farentinos (1985:6) mengatakan bahwa terdapat beberapa jenis latihan plyometrick antara lain squat jump dan knee tuck jump. Squat jump adalah salah satu bentuk latihan pliometrick yang bertujuan untuk meningkatkan power tungkai dengan cara melompat dengan tolakan kedua kaki mengeper dan posisi tubuh kembali ke sikap awal. Sementara knee tuck jump adalah salah satu bentuk latihan plyometrick yang bertujuan untuk meningkatkan power dengan cara melompat keatas dengan tolakan kedua kaki, posisi lutut dilipat tinggi dan telapak tangan menyentuh lutut. Kedua bentuk latihan tersebut sama sama dilakukan dengan cara melompat, namun perbedaan dari kedua gerakan tersebut adalah squat jump melompat/dengan kedua kaki lurus dan knee tuck jump melompat dengan lutut dilipat tinggi (ditekuk).

Dojo Inkanas PT.Sinar Sosro Tanjung Morawa didirikan pada Tahun 2002 dengan tujuan sebagai wadah untuk melatih murid (karateka) yang berbakat dalam bela diri karate, dojo Inkanas PT.Sinar Sosro Tanjung Morawa ini sudah banyak mengikuti kejuaraan namun dari tahun ketahun mengalami penurunan prestasi hal ini dapat dilihat pada tahun 2007 dojo Inkanas PT. Sinar Sosro Tanjung Morawa pernah menjadi juara III umum kejurda Inkanas sumut. Tahun 2012 sempat menjadi juara II umum kejurda Inkanas sumut, namun pada kejurda Inkanas sumut tahun 2016 dojo Inkanas PT.Sinar Sosro tidak lagi dapat mempertahankan maupun meningkatkan prestasi pada ajangajang yang ada.

Dari data terebut terlihat hasil prestasi yang diraih oleh dojo PT. Sinar Sosro Tanjung Morawa dari tahun ke tahun semakin menurun. Sehingga timbul pertanyaan dalam diri peneliti yaitu "mengapa prestasi yang diraih para karateka Inkanas dojo PT.Sinar Sosro tidak meningkat dari tahun ketahun. Jika dibandingkan dengan lamanya berdiri dojo ini, prestasi yang diperoleh tergolong masih kurang baik. Dari sekian banyak kejuaraan yang diikuti tetapi hanya sedikit prestasi yang diperoleh. Dari data diatas, peneliti tertarik untuk meneliti penyebab sedikitnya prestasi yang telah mampu diukir oleh dojo PT. Sinar Sosro Tanjung Morawa ini yang sudah berdiri 15 tahun 
silam. Dengan ketertarikan tersebut, peneliti berinisiatif melakukan observasi pada kegiatan latihan yang dilakukan oleh altet karate Inkanas dojo PT. Sinar Sosro Tanjung Morawa. Disamping itu, peneliti juga melakukan wawancara langsung pada tanggal 6 Maret 2017 dengan pelatih dojo PT. Sinar Sosro Tanjung Morawa yaitu Senpai Uli Saut Purba (DAN V KARATE).

Di dalam beladiri Karate secara umum terdapat teknik tendangan yang bervariasi, tetapi pada dasarnya bersumber pada empat sisi telapak kaki yaitu ; punggung kaki, ujung telapak kaki, sisi telapak kaki, dan tumit. Menurut Masutatsu Oyama dikutip oleh Sujoto (1996: 98), mengemukakan bahwa : " Kira-kira 70\% beladiri menggunakan teknik tendangan dan kekuatan tendangan kurang lebih lima kali lebih besar dari teknik pukulan, kenyataannya masih banyak karateka Inkanas dojo PT Sinar Sosro Tanjung Morawa yang belum bisa mengaplikasikan teknik tendangan tersebut secara sempurna dan salah satu penyebabnya adalah kurangnya power tungkai karateka Inkanas dojo PT Sinar Sosro Tanjung Morawa. Hal ini jauh dari harapan mengingat salah satu keberhasilan karateka untuk dapat memperoleh prestasi terbaik pada saat menjalani pertandingan adalah harus mampu melancarkan serangan, menampilkan power tungkai dan teknik tendangan yang baik. Permasalahan yang muncul dari hasil observasi pada tanggal 3, 5 dan 7 Maret 2017 adalah kurangnya power tungkai karateka Inkanas dojo PT Sinar Sosro yang terlihat dari kecepatan tendangan dan pergerakan tungkai yang kurang baik.

\section{B. METODE PENELITIAN}

Penelitian dilaksanakan di dojo karate Inkanas PT.Sinar Sosro tanjung morawa yang berlokasi di Jalan Raya Medan Tanjung Morawa KM 14,5 Kabupaten Deli Serdang pada bulan april-juni 2017. Subyek penelitian berjumlah 20 orang. Metode yang digunakan dalam penelitian ini adalah metode eksperimen dengan teknik pengambilan data yang melibatkan dua variabel bebas yaitu latihan squat jump dan latihan knee tuck jump terhadap satu variabel terikat yaitu power tungkai.

Desain dalam penelitian ini menggunakan pre test and post test two group design. Artinya terlebih dahulu membagi dua kelompok yaitu secara matching pairing yaitu kelompok A yang diberikan perlakuan latihan squat jump dan kelompok B yang diberikan perlakuan latihan knee tuck jump. Tes akhir dilakukan setelah sampel 
eksperimen diberikan perlakuan tiga kali seminggu selama 6 minggu (18 kali pertemuan).

Prosedur penelitiannya adalah, pertama sekali dilakukan pengambilan sampel dengan menggunakan teknik purposive sampling pada karateka dojo PT Sinar Sosro Tanjung Morawa. Maka diperoleh sebanyak 20 karateka yang berhak menjadi sampel tetap dalam penelitian ini. Selanjutnya diadakan test awal terhadap 20 orang tersebut untuk mengetahui kemampuan awal power tungkai sampel. Setelah hasil test awal diperoleh maka sampel dirangking berdasarkan urutan hasil perolehan test awal sampel mulai dari test yang tertinggi hingga yang terendah. Kemudian sampel menjadi dua kelompok dengan teknik matching pairing.

Setiap kelompok terdiri dari 10 orang, setelah itu barulah di berikan perlakuan latihan squat jump untuk kelompok A sesuai dengan program latihan. Dan kelompok B diberikan perlakuan latihan knee tuck jump. Dengan jumlah keseluruhan 18 kali latihan, frekuensi latihan 3 (tiga) kali seminggu, selama kurang lebih 6 minggu, setelah sampel telah selesai menjalakan program latihan sebanyak 18 kali latihan maka sampel diistirahatkan selama $1-2$ hari, kemudian setelah itu dilakukan test akhir (post test) untuk mengetahui power tungkai. Setelah di dapat pre test dan post test maka dilakukan perhitungan melalui rumus statistik untuk membuktikan hipotesis yang dilakukan diterima atau ditolak

Data hasil tes power tungkai yang telah diperoleh (pre-test dan post- test) diolah dengan menggunakan prosedur stastistik. Sebelum dilakukan uji analisis, maka terlebih dahulu dilakukan uji persyaratan analisis, yaitu:
1. Uji Normalitas
2. Uji Homogenitas

Bila data dinyatakan normal dan homogen, maka dilanjutkan uji analisis dengan menggunakan uji-t.

- Mencari t-hitung

$$
t=\frac{B^{2}}{S b / \sqrt{n}}
$$

- Uji berpasangan

$$
t=\frac{\bar{X}_{1}-\bar{X}_{2}}{s G \sqrt{\frac{1}{n_{1}}+\frac{1}{n_{1}}}}
$$




\section{HASIL PENELITIAN DAN PEMBÄASAN}

\section{HASIL PENELITIAN}

Dari hasil pre test pada kelompok latihan Squat Jump terhadap peningkatan Power tungkai diperoleh rentang antara 33-52 dengan rata-rata 42,9 dan simpangan baku 5,45. Dari hasil post test diperoleh rentang antara 40-62 dengan rata-rata 52 dan simpangan baku 6,45. Dari rata-rata pre test dan post test didapat nilai beda 9,1 dengan simpangan baku beda 1,60 sehingga didapat nilai thitung 17,84 .

Dari hasil pre test pada kelompok latihan Knee tuck jump terdapat peningkatan Power tungkai diperoleh rentang antara 33 - 49 dengan rata-rata 42,3 dan simpangan baku 5,29. Dari hasil post test diperoleh rentang antara 42 - 60 dengan rata-rata 52,7 dan simpangan baku 6,18. Dari rata-rata pre test dan post test didapat nilai beda 10,4 dengan simpangan baku beda 1,35. Sehingga di dapat $t_{\text {hitung }} 24,19$. Dari pengolahan data akhir didapat nilai simpangan baku gabungan sebesar 6,31, sehingga didapat $t_{\text {hitung }}$ gabungan sebesar 0,246.

Hasil Pre Test dan Post Test Latihan Squat Jump dan Knee tuck Jump Terhadap Power Tungkai

\begin{tabular}{|c|c|c|c|c|}
\hline \multirow{3}{*}{ Deskripsi Data } & \multicolumn{4}{|c|}{ Power Otot Tungkai } \\
\hline & \multicolumn{2}{|c|}{ Squat Jump } & \multicolumn{2}{|c|}{ Knee tuck Jump } \\
\hline & Pre test & Post Test & Pre test & Post test \\
\hline Nilai Rata-Rata & 42,9 & 52 & 42,3 & 52,7 \\
\hline Simpangan Baku & 5,45 & 6,45 & 5,29 & 6,18 \\
\hline Beda Rata-Rata & \multicolumn{2}{|c|}{9,1} & \multicolumn{2}{|c|}{10,4} \\
\hline Simpangan Baku Beda & \multicolumn{2}{|c|}{1,60} & \multicolumn{2}{|c|}{1,35} \\
\hline$t_{\text {hitung }}$ & \multicolumn{2}{|c|}{17,84} & \multicolumn{2}{|c|}{24,19} \\
\hline $\mathrm{t}_{\text {tabel }}$ & \multicolumn{2}{|c|}{1,83} & \multicolumn{2}{|c|}{1,83} \\
\hline Simpangan Baku Gabungan & \multicolumn{4}{|c|}{6,31} \\
\hline$t_{\text {hitung }}$ & \multicolumn{4}{|c|}{0,246} \\
\hline$t_{\text {tabel }}$ & \multicolumn{4}{|c|}{2,10} \\
\hline
\end{tabular}

\section{Uji Normalitas}

Pengujian normalitas data dengan menggunakan uji Lilifors, dari kolom daftar pre test latihan Squat Jump untuk power tungkai didapat $\mathrm{L}_{0}=0,1259$ dan $\mathrm{L}_{\text {tabel }}=$ 0,2580 dengan $\mathrm{n}=10$ dan taraf nyata $\alpha=0,05$ karena $\mathrm{L}_{\mathrm{o}}<\mathrm{L}_{\text {tabel }}$ dapat disimpulkan bahwa sampel berasal dari populasi yang normal. Dari kolom data post test latihan Squat Jump untuk power tungkai didapat $\mathrm{L}_{\mathrm{o}}=0.0809$ dan $\mathrm{L}_{\text {tabel }}=0,2580$ dengan $\mathrm{n}=10$ 
dan taraf nyata $\alpha=0,05$, karena $\mathrm{L}_{\mathrm{o}}<\mathrm{L}_{\text {tabel }}$ dapat disimpulkan bahwa sampel berasal dari populasi yang normal. Dari kolom data pre test latihan Knee tuck Jump untuk Power tungkai didapat $\mathrm{L}_{0}=0.1027$ dan $\mathrm{L}_{\text {tabel }}=0,2580$ dengan $\mathrm{n}=10$ dan taraf nyata $\alpha=$ 0,05 karena $\mathrm{L}_{\mathrm{o}}<\mathrm{L}_{\text {tabel, }}$ dapat disimpulkan bahwa sampel berasal dari populasi normal. Dari kolom daftar post test latihan Knee tuck Jump untuk power tungkai didapat $\mathrm{L}_{\mathrm{o}}=$ 0,0936 dan $\mathrm{L}_{\text {tabel }}=0,2580$ dengan $\mathrm{n}=10$ dan taraf nyata $\alpha=0,05$. Karena $\mathrm{Lo}<\mathrm{L}_{\text {tabel }}$ dapat disimpulkan bahwa sampel bersal dari populasi yang normal.

\section{Uji Homogenitas}

Uji homogenitas data pre test untuk peningkatan power tungkai antara kelompok latihan Squat Jump dengan Knee tuck Jump didapat $\mathrm{F}_{\text {hitung }}=1,06$ diketahui bahwa $\mathrm{n}_{1}=$ 10 , dk penyebut $=10-1=9$, sedangkan $\mathrm{dk}$ pembilang $=10-1=9$, sehingga didapat $\mathrm{F}_{0,05(5,5)}=3,18$ pada taraf nyata $\alpha=0,05$, maka $F_{\text {hitung }}<\mathrm{F}_{\text {tabel }}$ atau 1, $06<3,18$. Dapat disimpulkan bahwa kedua varian adalah homogen. Uji homogenitas data Post Test untuk power tungkai antara kelompok latihan Squat Jump/dengan latihan Knee tuck Jump didapat $\mathrm{F}_{\text {hitung }}=1,09$ diketahui bahwa $\mathrm{n}_{1}=10$, $\mathrm{dk}$ penyebut $=10-1=9$, sedangkan dk pembilang $10-1=9$ sehingga didapat $\mathrm{F}_{0,0}(5,5)=3,18$ pada taraf nyata $\alpha=$ 0,05, maka $F_{\text {hitung }}<F_{\text {tabel }}$ atau $1,09<3,18$. Dapat disimpulkan bahwa kedua varian adalah homogen.

\section{Uji Hipotesis}

Berdasarkan hasil perhitungan yang dilakukan dapat diperoleh pengujian

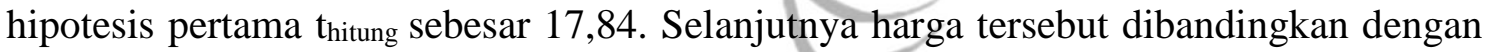
harga $t_{\text {tabel }}$ dengan $\mathrm{dk}=\mathrm{n}-1(10-1=9)$ pada taraf signifikan $\alpha=0,05$ adalah 1,83 dengan demikian $t_{\text {hitung }}>\mathrm{t}_{\text {tabel }}$ atau 17,84 >1,83 hal ini berarti Ho ditolak dan Ha diterima. Dengan demikian dapat disimpulkan bahwa secara signifikan latihan Squat Jump berpengaruh terhadap peningkatan Power tungkai Karateka Inkanas Dojo PT. Sinar Sosro Tanjung Morawa Tahun 2017.

Berdasarkan hasil perhitungan yang dilakukan maka diperoleh pengujian hipotesis kedua thitung sebesar 24,19. Selanjutnya harga tersebut dibandingkan dengan harga tabel dengan $\mathrm{dk}=\mathrm{n}-1(10-1=9)$ pada taraf signifikan $\alpha=0,05$ adalah 1,83 dengan demikian $t_{\text {hitung }}>$ dari $t_{\text {tabel }}$ atau $24,19>1,83$. Hal ini berarti Ho ditolak dan Ha diterima. Dengan demikian dapat disimpulkan bahwa secara signifikan latihan Knee 
tuck Jump berpengaruh terhadap peningkatan power tungkai Karateka Inkanas Dojo PT. Sinar Sosro Tanjung Morawa Tahun 2017.

Berdasarkan hasil perhitungan yang dilakukan maka diperoleh pengujian hipotesis ketiga $t_{\text {hitung }}$ sebesar 0,246. Selanjutnya harga tersebut dibandingkan dengan harga $t_{\text {tabel }}$ dengan $d k=n_{1}+n_{2}-2=10+10-2=18$ pada taraf signifikan $\alpha=0,05$ adalah 2,10 dengan demikian thitung $<t_{\text {tabel }}$ atau 0,246 < dari 2,10. Hal ini berarti Ho diterima dan Ha ditolak. Dengan demikian dapat disimpulkan bahwa secara signifikan latihan Squat Jump tidak lebih besar pengaruhnya dibandingkan dengan latihan Knee tuck Jump terhadap peningkatan power tungkai Karateka Inkanas Dojo PT. Sinar Sosro Tanjung Morawa Tahun 2017.

\section{PEMBAHASAN PENELITIAN}

Pembahasan hasil analisis data penelitian dimaksud untuk mempermudah dalam menarik kesimpulan hasil penelitian. Menurut A Chu (1992:81) Pliometrick adalah latihan latihan khusus yang melatih otot-otot untuk meningkatkan kekuatan maksimum yang lebih cepat. Jadi latihan pliometrik adalah metode yang lebih mengarah kepada pengembangan power yang beguna untuk meningkatkan daya ledak, kecepatan dan kelentukan.

Dari hasil pengujian hipotesis pertama menunjukan bahwa terdapat pengaruh yang signifikan antara Pre Test dan Post Test pada kelompok latihan Squat Jump terhadap peningkatan power tungkai karateka Inkanas Dojo PT. Sinar Sosro Tanjung Morawa Tahun 2017. Seperti yang dikemukakan oleh Harsono (1988:101):'Latihan adalah proses yang sistematis dari berlatih dan bekerja yang dilakukan secara berulangulang dengan kian hari menambah beban latihan dan pekerjaannya".

Bentuk latihan Squat Jump dapat dilakukan secara berkelompok atau sendirisendiri. Squat jump adalah salah satu latihan pliometrik yang dilakukan dengan cara mengggerakan otot utama pada bagian paha dan betis pada kecepatan tertentu. Gerakan Squat jump dilakukan dengan cara memberikan tekanan pada otot paha dan betis. Latihan squat jump ini merupakan bentuk latihan meloncat ke atas dengan kedua kaki lurus. Latihan ini dapat dilakukan pada permukaan yang rata dan dilakukan setengah perpegas. Gerakan squat jump bertujuan untuk melatih kontraksi dari otot otot tungkai yang sangat berperan terhadap daya ledak (eksplosive) dari gerakan tungkai tersebut. Dalam penelitian ini hal tersebut terbukti bahwa terdapat pengaruh dari latihan Squat 
jump yang disesuaikan dengan prinsip prinsip latihan terhadap peningkatan power tungkai.

Dari hasil pengujian hipotesis yang kedua menunjukan bahwa terdapat pengaruh yang signifikan antara Pre Test dan Post Test pada kelompok latihan Knee tuck Jump terhadap peningkatan power tungkai karateka Inkanas Dojo PT. Sinar Sosro Tanjung Morawa Tahun 2017. Seperti yang dikemukakan oleh Harsono (1988:101):'Latihan adalah proses yang sistematis dari berlatih dan bekerja yang dilakukan secara berulangulang dengan kian hari menambah beban latihan dan pekerjaannya".

Latihan knee tuck jump pada dasarnya merupakan bentuk latihan pliometrick yang bertujuan untuk meningkatkan power tungkai, dimana hal tersebut merupakan salah satu kondisi fisik yang sangat dibutuhkan pada cabang olahraga beladiri karate. Bentuk dari latihan Knee tuck Jump yaitu dengan berdiri tegak lurus pada bidang datar, kemudian meloncat ke atas dengan lutut diangkat tinggi ke depan dada.. Tujuan latihan Knee tuck Jump adalah untuk meningkatkan power tungkai. Jika dianalisa gerakan knee tuck jump membutuhkan daya kontraksi yang cepat dikarenakan gerakan knee tuck jump harus dilakukan dengan lompatan dimana lutut harus menyentuh kedua tangan di dada dengan kecepatan yang tinggi. Gerakan knee tuck jump dapat merangsang kecepatan reaksi otot-otot tungkai. Dalam penelitian ini hal tersebut terbukti secara nyata bahwa terdapat pengaruh dari latihan knee tuck jump yang disesuaikan dengan prinsip-prinsip latihan terhadap peningkatan power tungkai.

Dari hasil pengujian hipotesis yang ketiga menunjukan bahwa tidak lebih besar pengaruh latihan Squat Jump dibandingkan latihan Knee tuck Jump terhadap power tungkai karateka Inkanas Dojo PT. Sinar Sosro Tanjung Morawa Tahun 2017. Jika dilihat latihan squat jump dan knee tuck jump merupakan bentuk latihan yang samasama bertujuan untuk meningkatkan power tungkai dan menyebabkan otot-otot tungkai terus berkontraksi yang sangat dibutuhkan pada saat melakukan gerakan eksplosive. Kedua latihan tersebut sama sama dilakukan dengan cara melompat. Perbedaan pada gerakan ini adalah gerakan squat jump melompat dengan kedua kaki lurus, sementara gerakan knee tuck jump adalah gerakan melompat dengan kedua kaki ditekuk dengan lutut menyentuh kedua tangan yang berada di depan dada.

Pada pelaksanaannya knee tuck jump lebih membutuhkan kontraksi otot tungkai yang lebih cepat dibandingkan dengan latihan squat jump dikarenakan latihan knee tuck 
jump harus melompat dengan lutut menyentuh ke tangan yang berada di depan dada yang lebih merangsang kecepatan kontraksi dan refleks dari otot-otot tungkai. Dalam penelitian ini latihan squat jump tidak lebih baik daripada latihan knee tuck jump terhadap peningkatan power tungkai karateka Inkanas dojo PT Sinar Sosro. Namun terdapat beberapa faktor yang mempengaruhi berhasil atau tidaknya program latihan yang diberikan kepada atlet. Menurut Harsono (1988:176)"Power adalah hasil dari kekuatan dan kecepatan". Kedua komponen fisik tersebut juga sangat dipengaruhi dari faktor motivasi, mental, kondisi kesehatan atlet, gizi, faktor lingkungan pada saat melaksanakan latihan dan faktor jenis tipe serabut otot atlet.

Menurut Hairy (1989:36):"Otot terbagi menjadi dua macam, yaitu otot merah dan otot putih. Serabut otot merah lebih cocok/sesuai untuk kegiatan yang berlangsung dalam waktu yang lama, kontraksi yang lambat, untuk menyanggah postural, pekerjaan pekerjaan otot untuk melawan gaya tarik bumi, sedangkan otot putih sangat sesuai dengan kegiatan-kegiatan yang bersifat cepat, dan karena itu sangat banyak ditemukan pada otot-otot flexor." Dalam penelitian ini disimpulkan bahwa latihan Squat Jump tidak lebih besar pengaruhnya dari latihan Knee tuck Jump terhadap peningkatan power tungkai karateka Inkanas Dojo PT. Sinar Sosro Tanjung Morawa Tahun 2017.

\section{KESIMPULAN}

1. Terdapat pengaruh yang signifikan dari latihan Squat Jump terhadap peningkatan power tungkai karateka Inkanas Dojo PT. Sinar Sosro Tanjung Morawa Tahun 2017.

2. Terdapat pengaruh yang signifikan dari latihan Knee tuck Jump terhadap peningkatan power tungkai karateka Inkanas Dojo PT. Sinar Sosro Tanjung Morawa Tahun 2017.

3. Squat Jump tidak lebih besar pengaruhnya dibandingkan dengan latihan Knee tuck Jump terhadap peningkatan power tungkai karateka Inkanas Dojo PT. Sinar Sosro Tanjung Morawa Tahun 2017.

\section{Daftar Pustaka}

Arikunto, Suharsimi (1998). Prosedur Penelitian Suatu Pendekatan, Praktek. Yogyakarta: IKIP

Bompa, Tudor O. (1983). Theory and Methodology of Training. Dubuque, IOWA: Kendal/Hunt Publishing Company. 
Chu, A. Donald. (1992). Jumping Into Plyometrics. England : Leisure Press.

Hairi, Junusul. (1989). Fisiologi Olahraga. Padang : Departemen Pendidikan dan Kebudayaan Direktorat Jendral Pendidikan Tinggi Proyek Pengembangan Lembaga Pendidikan Tenaga Pendidikan Jakarta

Harsono. (1988). Coaching dan Aspek-Aspek Psikologis dalam Coaching. Jakarta: Akademik Pesindo.

Langley, L.L., Telford, Ira.R., Christensen, John. B., (1980). Dynamic Anatomy and Physiology:United States of America,

Nurhasan. (2001). Tes dan Pengukuran dalam Pendidikan Jasmani. Jakarta: Depdiknas.

Purba. (2014). Prosedur Pelaksanaan tes Kondisi Fisik/Tes Fisiologi Atlet. Bandung: Departemen Ilmu Faal Fakultas Kedokteran Universitas Padjajaran Bandung.

Radclife, JC dan Robet, C. Farentinous, (1994). Explosive Power Training, Illions. Human Kinetik Publisher.Inc

Sajoto, M. (1988).Pembinaan Kondisi Fisik dalam Olahraga. Jakarta: Depdikbud.

Simbolon, Bermanhot. (2013). Latihan dan Melatih Karateka, Medan : Griya Pustaka

Sudjana, (2005). Metode Statistika. Bandung: PT.ARSITO BANDUNG

Sujoto, J.B. (1996). Teknik Oyama Karate. Jakarta: Gramedia.

Wahid, Abdul. (2007). Shotokan. Jakarta:PT GrajafindoPersada

Widjaja, Surya. (1998). Kinesiologi. Jakarta: Balai Penerbit FKUI

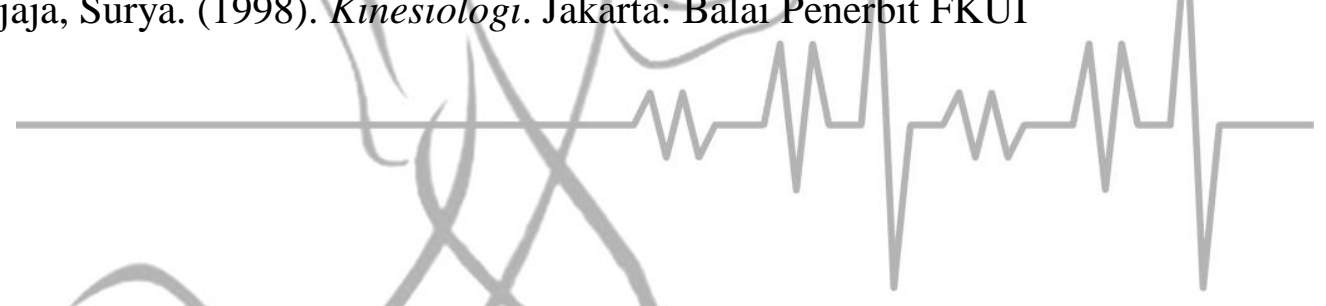

